\title{
АНАЛИЗ ТЕКУЩЕГО СОСТОЯНИЯ СТРАТЕГИИ ИМПОРТОЗАМЕЩЕНИЯ В РФ
}

\author{
(c) 2018 Кшнякин Петр Андреевич \\ заведующий лабораторией систем искусственного интеллекта в медицине \\ Самарский государственный медицинский университет Министерства \\ здравоохранения Российской Федерации \\ 443099, Российская Федерация, г. Самара, ул. Чапаевская, 89 \\ E-mail:kshnjakin@yandex.ru
}

В статье рассматривается проблема организации импортозамещения в Российской Федерации. Описывается текущее состояние, проблемы и основные тенденции. Отмечены эффективные и неэффективные векторы решения проблемы.

Ключевые слова: управление инновациями, инновации, импортозамещение, медицина, стратегии, тенденции, эффективность.

Проблема организации масштабного импортозамещения в российской экономике приобретает особо острый характер в дискуссиях как теоретиков, так и практиков-управленцев в условиях вызовов, порожденных существующим геополитическим кризисом. Многие правительственные документы стали посвящаться данной теме, в том числе законы, стратегические направления, целевые программы, ведомственные руководящие документы и т.д. В Послании Президента РФ Федеральному собранию отмечается важность поддержки конкурентоспособных отечественных предприятий при их работе с ориентацией на внутренней и мировой рынки, выпускающих качественную продукцию [3]. Правительством РФ к настоящему моменту подготовлено свыше тысяч вариантов по проблеме реализации импортозамещения в наиболее критичных к санкциям отраслях: отрасли добычи нефти и газа, инфокоммуникационных отраслях и программном обеспечении, комплектующих к продукции военной техники, сельскохозяйственного машиностроения и так далее. Это должны обеспечить независимость предприятий от импортных поставок. Внедрение намеченных проектов даст возможность и самым чувствительным секторам, таким как станкостроению, уменьшить процент импортозависимости с 88 процентов до 40 уже к 2020-му г. В этих целях потребуются материальные вложения порядка 159 миллиардов рублей. Однако, согласно данных предварительных подсчетов в ближайшие 20 лет реализация намеченных проектов привлечет в бюджет РФ дополнительные средства в размере до 2,2 триллионов рублей, а это увеличит объем бюджетных средств в 13,6 pa3 [2].

В условиях бюджетных ограничений тщательно прописываются полномочия министерств, предусматривающие установление характера действий по планированию и проведению госзакупок, а также порядок определения инвестпроектов с господдержкой. Разрабатывается комплекс мероприятий направленных на координацию госзакупок критически важного перечня в целях экономической безопасности страны зарубежного технологического оборудования, улучшения условий доступа российских компаний-производителей в закупках крупных корпораций, особенно в рамках реализации масштабных инвестиционных проектов, создание преимущественных условий для российских поставщиков товаров и услуг для государственных и муниципальных нужд. В этих условиях промышленная политика страны становится категорией национальной безопасности.

Евдокимов Н.Н., Жичкин Ю.В. отмечают в этой связи, что несмотря на засилье импортной продукции потребительского и производственного назначения во все пореформенное время, критичной данная проблема для отечественной экономики стала вместе с ухудшением внешнеэкономических и политических факторов, проявившихся во взаимоотношениях со странами Запада, а также высокой волатильностью валютного курса рубля, и вызванного этим удорожания импорта инвестиционного оборудования и сложной технической продукции, негативно отражающейся на себестоимости продукции отечественных предприятий и самой возможности выпускать нужную для общества продукцию. Наряду с необходимостью обеспечения безо- 
пасности государства (военной, экономической, технической, продовольственной и т.п.), усиленное внимание к данной проблеме вызвана также интересами бизнеса, стремящегося снижать внешнеторговые и валютные риски посредством перехода к работе с отечественными поставщиками, предприятий стран ЕАЭС [10].

Признавая высокую важность, многие авторы полагают, что явление импортозамещения требует законодательного закрепления в руководящих документах государства, чтобы содержательно определить стратегическую нацеленность данной экономической политики (Евдокимов Н.Н., [10] Жичкин Ю.В., [10] Жабин А.П., [5] Волкодавова Е.В., [5] Карсунцева О.В., [6] Александрова А.Р. и др. авторы. [4, 7, 8, 9]). При этом следует отметить, что подавляющее большинство специалистов считают необходимость организацию работ по широкому импортозамещению в национальной сложившейся ситуации и обсуждения ведутся по большей части о скорейшей постановке импортозамещения в народнохозяйственных масштабах.

Объективная реальность доказывает, что импортозамещение на территории нашей страны постепенно сходит на нет, это следует из индикаторов розничной торговли и доказывает прирост торговли импортными продуктами. Так, по итогам 2017-го года из зарубежных стран привезено в 4 раза больше масла растительного происхождения, в 2 раза больше картофеля, чеснока, лука. В 2018 году импортозамещение изменилось в положительную сторону. К примеру в Кумторкалинском районе Дагестана открыт один из самых крупных в России тепличный комплекс «Югагрохолдинг», в Сернурском районе Марий Эл - крупная козья ферма, в Тольятти - фармацевтический завод «Озон Фарм». В Выборгском районе Ленинградской области на СХП «Лосево» открыто и успешно развивается производство молока без лактозы, в Новороссийске расширяется в лице завода «Брис-Босфор» расширяется обувная промышленность, а в Сахалинской области планируется строительство плавающего завода, который будет заниматься переработкой морской рыбы. Официальные данные Федеральной службы государственно статистики также очень оптимистичны. Итоги 2017-го г. показывает, что производство фруктов, ягод и орехов возросло на 85 процентов. Те же данные по свежим рыбным продуктам возросли на 28 процентов, замороженным на 4 процента.
Однако есть и негативные моменты, которые растут. Параллельно с ростом цены на нефть (за прошедшие шесть месяцев цена нефти выросла в 1,5 раза - с 48 до 69 долларов за баррель) наблюдается рост выручки от экспортной продажи сырья. В соответствии с подсчетами Федеральной таможенной службы закупки изза рубежа также растут. Так по данным 11 месяцев 2017 года транспортных средств, электрического оборудования закуплено и привезено на территорию России на 27 процентов больше, большегрузных автомобилей на 54 процента. Импортирование обуви выросло на 14 процентов, хлопчатобумажной ткани на 52 процента, на 11 процентов больше завезено средств для защиты растений. Несмотря на то, что импортозамещение пропагандируется в России, факты доказывают, что их ввоз на территорию РФ упрямо растет [11].

Так официальные статистические данные 11 мес. 2017-го года показывают, что в значительно больших количествах закупается растительное масло, виноград, лук, чеснок, картофель, капуста, молоко. Также в больших количествах закупается мясо (не исключение - птица), рыба, сливочное масло. В то время как производительная активность молока остановилась на уровне 2015 года - 30,7 млн. тон, а это всего 80 процентов от необходимого населению количества. Кроме того согласно сведениям Федеральной таможенной службы в 2017 году кукуруза закуплена на 1/3больше, ячмень на 14 процентов. Как это ни парадоксально, но Россия закупает за рубежом даже пшеницу, но в 2017 году уже меньше чем в 2016-м (247 т). И это все несмотря на то, что эти товарные группы включены в основную часть списка замещения, который реализуется государственной политикой в последние годы.

2018 год, по всей видимости, эту ситуацию не поправит. Этому росту способствовали как санкции и запреты, так и падение российской валюты, которое наиболее сильно проявилось в период 2014-2015 года. На протяжении 2018 года российская валюта, то есть рубль должна быть более стабильной, конечно при отсутствии провоцирующих ситуаций. Однако импорт в 2018 году продолжит свой рост, что негативно скажется на импортозамещение, а население будет приобретать западные товары. По большей части это вызвано, тем, что производители нашей страны не способны бороться с конкуренцией, в частности в соотношении цена-качество. В частности этим 
«страдает» машино- и судостроение, потому в таких сферах предпочтение население страны отдает западным производителям. В то время как такие сферы как производство молочных продуктов, сыров, выращивание фруктов и овощей в России достаточно конкурентоспособные отрасли. Так сыры, которые ввиду санкций перестали ввозиться в Россию, стали производится отечественными производителями, по качеству не хуже зарубежных.

Для того чтобы поддержать импортозамещение на данный момент целесообразнее будет не запрещать, а софинансировать денежные средства из бюджета, предоставлять льготные условия инвестиционным проектам. Однако эти вопросы не определены, не стабильны и не прозрачны. На сегодняшний день наиболее важно не само импортозамещение, а повышение качества отечественного производства, а также глубокая переработка сельскохозяйственного сырья. Другим, не менее важным аспектом является оказание поддержки экспорту продовольственных товаров, в частности в страны Азиатско-Тихоокеанского региона.

Закупка не продуктовых товаров импортного производства выросла практически в три раза, и это в не зависимости с активно пропагандируемой государственной программой по замещению импорта. В соответствии с мнением специалистов импорт растет в связи с укреплением национальной валюты, а также в связи с недостаточными показателями качества отечественных товаров. Так замещение импортных товаров оправданно в оборонных отраслях и положительно сказывается на сельскохозяйственном производстве, в то время как остальным отраслям оно не идёт на пользу. Это мнение экономистов.

Согласно данным ФТС за 11 месяцев 2017 года закупка импортных товаров выросла на 24,1 процент или на 181,4 млрд. \$ [11].

За тот же период ввоз импортных товаров химпродукции возрос на 19 процентов (этот показатель равен 33.4 млрд. \$). В эту же группу включается ввоз фармацевтической продукции, косметики, парфюмерии, полимерных материалов, каучука, моющих средств. Ввоз импортных товаров текстильного назначения и обуви увеличился на 30.8 процентов и составил 10.9 млрд. \$. Аналогичный показатель в машиностроении составил 27.9 процентов или 93,4 млрд. \$. Сюда входит также механическое и электрическое оборудование, оптические аппараты, инструменты. Если рассматривать транспортные средства, то это - наземный транспорт, летательные аппараты, суда, плавучие средства, железнодорожные локомотивы.

Рост ввоза импортных товаров наблюдается как в товарных, так и в финансовых показателях. При сравнении абсолютного объема ввоза импортных товаров в общем выражении за 10 месяцев 2017 г. и аналогичным периодом 2016-го наблюдается увеличение всех, за редким исключением, важных товаров непродовольственного назначения. К примеру, хлопчатобумажные ткани на 53 процента, черные металлы на 48.8 процента.

Сотрудниками РАНХиГС увеличение ввоза импортных товаров связано с укреплением рубля. При сопоставлении соотношения национальной валюты, доллара и цены на ввоз товаров (в \$) выходит, что взаимосвязанность указанных показателей реальна. Это соответствует предположению о том, что эффективность курса рубля имеет прямое воздействие на динамические показатели денежных объемов ввозимых импортных товаров. Если сравнить 8 месяцев 2016 года и 8 месяцев 2017 года, то национальная валюта выросла в соотношении с долларом на 19.9 процентов, что можно сопоставить с ростом ввоза импортных товаров в эти же периоды - 26.8 процентов.

В отношении многих товаров ввоз уменьшался уже в течение 2015 года, чему способствовала сильная девальвация рубля. К примеру, в соответствии с данными РАНХиГС при оценке показателей за период с 2014 по 2015 годы импорт в отношении транспорта и его комплектующих снизился на 30 процентов, однако затем импортозамещение прекратилось. В 2016 г. с укреплением национальной валюты ввоз импортных товаров стал расти.

Достаточно любопытный факт - программа, рассматриваемая в данной статье, активно пропагандируется и внедряется в РФ, однако рост импорта неумолимо растёт. С чем это связано? С двумя обстоятельствами - вводом западных санкций и ответными, аналогичными действиями РФ, а также уменьшением золотого содержания денежной единицы в условиях золотого стандарта национальной валюты, что привело к существенному подорожанию импортированных товаров в переводе на рубль.

Кроме импортозамещения товаров из-за 
рубежа, импорт которых увеличивается, руководящие слои нашей страны пытаются уменьшить ввоз промышленных товаров. Но государственные органы не отслеживают статистические данные импорта, особенно в приоритетных направлениях. Исключение - продовольственные товары, за которыми следит Федеральная служба государственной статистики.

\section{Библиографический список}

1. Хансевяров Р.И. Концептуальные основы формирования инновационной экономики // Вестник Самарского государственного экономического университета. Экономика. 2013. № 3 (101). С. 115-120

2. Постановление Правительства Российской Федерации от 15 апреля 2014 года N328 «Об утверждении государственной программы Российской Федерации «Развитие промышленности и повышение ее конкурентоспособности»»; Перечень поручений Президента РФ о дополнительных мерах по стимулированию экономического роста // http://kremlin.ru/acts/assignments/orders/23900; федеральный закон Российской Федерации, N488-Ф3 «О промышленной политике в Российской Федерации» от 31 декабря 2014 г. ст. 10-12, 16 и т.п.;

3. Послание Президента Федеральному собранию. URL: http://kremlin.ru/events/president/news/50864 (дата обращения 10.09.2018).

4. Стрижкова Л.А.Сводные оценки импортозависимости экономики и основных сегментов внутреннего рынка экономики// Москва. 2015 г Институт экономики РАН, Электронный ресурс: inecon.org/docs/ Strizhkova_paper_20151126.pdf, дата обращения 12 сентября 2018 г.

5. Волкодавова Е.В., Жабин А.П., Негонова Н.А. Развитие инструментов импортозамещения в современных условиях ведения бизнеса в промышленности Российской Федерации // Интернет-журнал «НАУКОВЕДЕНИЕ» Toм 8, № 2 (2016) http://naukovedenie.ru/PDF/90EVN216.pdf (доступ свободный). Загл. с экрана. Яз. рус., англ. DOI: $10.15862 / 90 E V N 2166$.

6. Карсунцева О.В., Российское машиностроение: курс на импортозамещение// Актуальные проблемы экономики и права.2016. № 1. С. 48-61.

7. Кшнякин П.А., Измайлов А.М. Проблемы импортозамещения медицинских изделий // Менеджмент предпринимательской деятельности. Материалы. Четырнадцатой научно-практической конференции. 2016. С. 493-496.

8. Вирясова Ю.В., Измайлов А.М. Кластеризация как инструмент реализации политики импортозамещения. // Менеджмент предпринимательской деятельности. Материалы. Четырнадцатой научно-практической конференции. 2016. С. 55-58.

9. Смолькин В.П., Яковлев Г.И., Измайлов А.М. Развитие сотрудничества России и Белоруссии в реализации политики импортозамещения. Современные вызовы и проблемы социального благополучия в России. Сборник работ по результатам Всероссийской научно-практической конференции. 2017. С. 182-188.

10. Евдокимов Н.Н., Жичкин Ю.В. О стратегическом подходе к организации государственной политики импортозамещения / // Вестник Самар. гос. экон. ун-та. 2016. № 2 (136). С. 18-27.

11. Официальный сайт ФТС - http://www.customs.ru/ Дата обращения 12 сентября 